\title{
The Concept of Landscape-Ecological Nodal Structures of the Development of the Regions of the Pacific Landscape Belt of the Landscape Sphere
}

\author{
Valeriy Titovich Starozhilov \\ Pacific International Landscape Center, Far Eastern Federal University, Vladivostok, Russia \\ Email: starozhilov.vt@dvfu.ru
}

How to cite this paper: Starozhilov, V. T. (2018). The Concept of Landscape-Ecological Nodal Structures of the Development of the Regions of the Pacific Landscape Belt of the Landscape Sphere. Journal of Geoscience and Environment Protection, 6, 176-184. https://doi.org/10.4236/gep.2018.612015

Received: November 19, 2018

Accepted: December 24, 2018

Published: December 27, 2018

Copyright $\odot 2018$ by author and Scientific Research Publishing Inc. This work is licensed under the Creative Commons Attribution International License (CC BY 4.0).

http://creativecommons.org/licenses/by/4.0/

\begin{abstract}
For the first time, the concept of landscape nodal structures is considered for the development of regions in the Pacific landscape belt of the landscape sphere that are promising for the development of territories. Landscape nodal structures are presented as a natural foundation for economic, social, ecological, and other forms of activity, which will enable us to consider tools of scientific and practical planning that are harmonized with the nature of forecasting economic, social, ecological and other geosystems. It is recommended, for the practical implementation of the concept, the compilation of new maps of nodal structures, as natural bases for creating models for the development of the territory. The cartographic separation of the landscape nodal structures as a whole will contribute to solving the problems of optimizing the natural environment of the regions.
\end{abstract}

\section{Keywords}

Landscape, Development, Nodal, Structure, Morphology, Mapping

\section{Introduction}

On planet Earth, the practical activity of society is carried out mainly in its near-surface part at the border of interaction between the layers of the geographic shell-the lithosphere, hydrosphere and atmosphere. The latter most intensively interacts in the landscape sphere named F.I. Milkovo-biological focus of the Earth. The very term landscape sphere was proposed by Yu.K. Efremov in 1950. The landscape sphere is a narrow part of the geographic shell, that 
is, that part of it, on the preservation of whose properties, attention is taken into account when solving local and regional nature management problems. At the same time, the landscape sphere is considered as a complex space-time dynamic system of poly-scale elements of inorganic and organic nature, resulting from the interpenetration, interdependence, and interaction of different geospheres. The complexity of the elements of the sphere determines the special relationship to the question of the significance of the objects of study, to the materials of the internal content of its components and vector-layered landscape structures, as well as their indication and structuring in terms of identifying the most favorable or not favorable for the development of structures.

At the same time, the landscape-ecological nodal structures of development are understood as the most favorable landscape morphological structures with natural characteristics that meet the requirements of society for conducting economic, social, ecological and other forms of activity necessary to meet the needs of society, i.e. they represent the natural foundation of the practical (economic, social, environmental, etc.) activities of society. However, to date, the question of nodal landscape-ecological structures for the development of geographical space has not previously been considered and is being put forward for the first time. During the development of territories it is negative that there are no cartographic materials on such structures, i.e. structures which, due to their favorable internal content, may be primarily involved in development. The absence of such cartographic documents, in turn, leads to negative consequences during the development of territories. Therefore, the study of the nodal landscape structures of the development of the regions of the Pacific landscape belt of the landscape sphere is relevant.

\section{Materials and Methods}

Theoretical and methodological foundations of research laid in the works of V.V. Dokuchaeva, L.S. Berg, A.N. Krasnova, G.F. Morozova, B.B. Polynova, L.G. Ramensky, N.A. Solntseva, D.L. Armand, V.B. Sochavy, A.G. Isachenko, V.A. Nikolaev, S.V. Preobrazhensky, F.N. Milkova K.N. Dyakonova, A.A. Retum, M. D Grodzinsky, G.E. Grishankova and many others. This article presents, taking into account the general landscape bases, the results of the author's field and theoretical studies in the field of landscape geography, which is considered a common methodological scientific basis, and its separation is a strategic landscape science and, in general, a landscape approach using geosystems. The work aimed at optimizing the development of the territories of the landscape sphere, the practical implementation of the landscape approach in solving production problems, examines the results of geological, geographical and geographical research of landscape geosystems of the Pacific landscape belt of Russia (Figure 1).

The landscape belt is the azonal belt of the landscape sphere with a genetically uniform structural-tectonic position in the zone of the continental marginal dichotomy of the ocean-continent system and characterized by the accretionary 


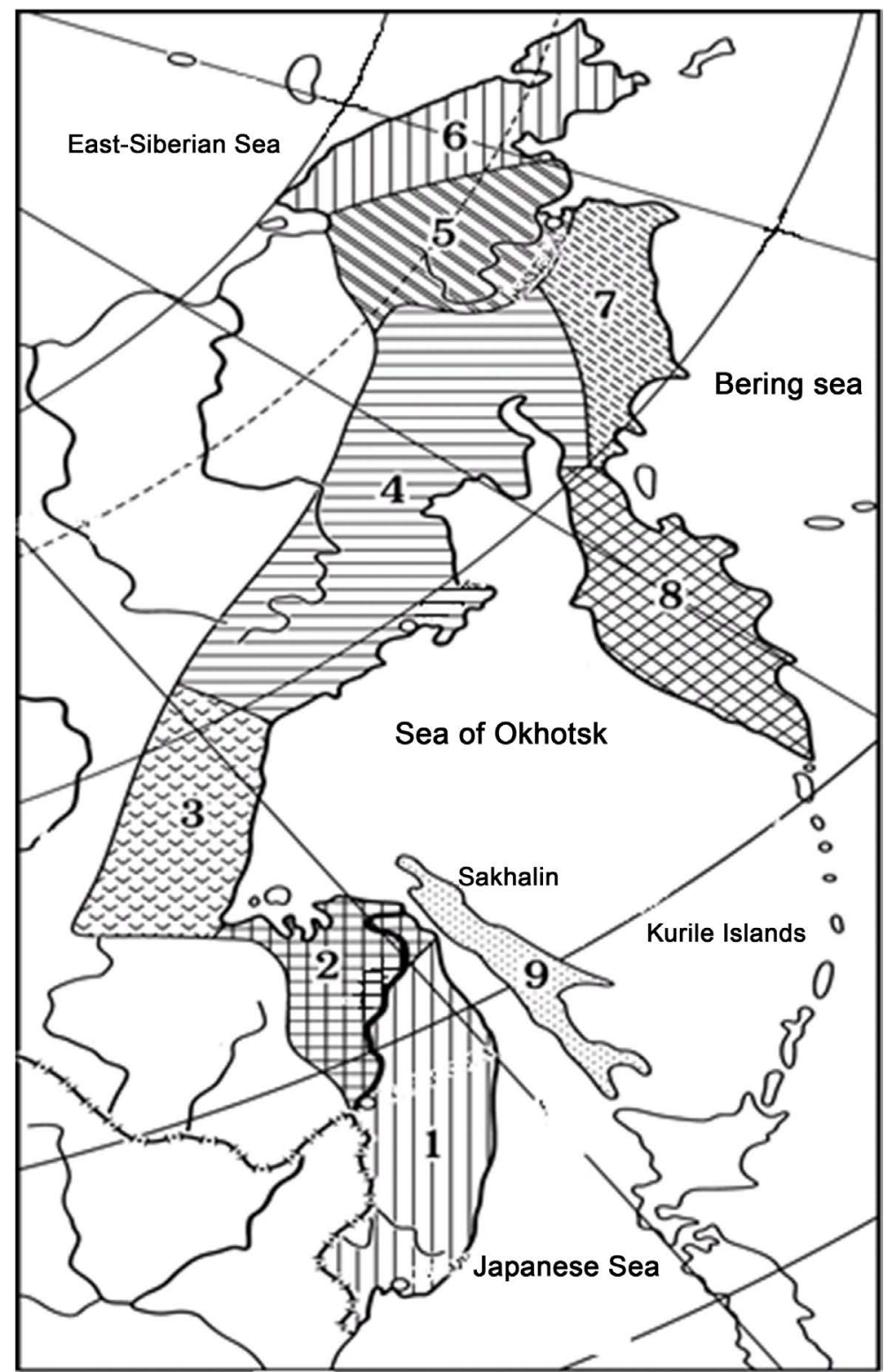

Belt areas: 1. Sikhote-Alinskaya, 2. Low-Amurskaya, 3. Priokhotskaya, 4. Kolymskaya, 5. Anadyrskaya, 6. Chukotskaya, 7. Koryakskaya, 8. Kamchatskaya, 9. Sakhalinskaya.

Figure 1. Pacific landscape belt of Russia.

nature of the foundation of the landscape Amur-Primorye, Priohotsk, Sakhalin, Kamchatka-Kuril, Chukotka and other geographical countries (structures) with climatic and vegetative internal content, obeying high-altitude and latitudinal zonality and evolving under the influence of interacting, interrelated and imopronikayuschih each other orographic, climatic factors and fitorastitelnogo (Starozhilov, 2013). Its peculiarity is not only in paleogeography, but also in the continental-oceanic dichotomy, the law of the fundamental dualism of land and sea, pairing in organization and functioning, unity and opposition of maritime and continental landscapes and geosystems. Landscape geosystems of the zone are considered in the field of mountain landscape science developing in recent 
decades. The landscape belt is a mountainous country, according to the landscape taxonomy there are no classical platform plains, and the available areas are parts of the mountain moving belts, rift structures.

On the basis of an in-depth component analysis in recent years, a landscape classification has been developed, a basic landscape map of Primorsky Krai M 1: 500,000 and a legend to it (Starozhilov et al., 2008; Starozhilov, 2010, 2011) has been compiled, the Sakhalin landscape classification has been developed at a scale of 1:500,000 of the region (Starozhilov, 2016), landscape research continues in other territories of the marginal continental part of Pacific Russia. For the first time, features of the formation of the foundation of landscapes of the Pacific landscape belt are shown on the basis of the author's concept of its accretionary geodynamic evolution, based on the study of the petrographic composition and structural-tectonic position of sedimentary and other lithocomplexes (Starozhilov, 1990, 2004a). Identified with examples of individual territories, features of the structure and organization of landscapes, a systematic analysis of their location over the territory, taking into account spatial-horizontal and high-altitude differentiation. A statistical assessment of the spatial distribution of landscapes and their quantitative parameters is given (Starozhilov, 2015b).

The medium and large-scale mapping of the territory, the use of regional-typological classification, correlated with landscape regionalization (Starozhilov et al, 2009a), allowed to reflect the features of geosystems in different parts of their ranges, and the description revealed the properties and degree of difference between them. In particular, in the structure of landscapes of Primorye, by analyzing the contingency and interrelationships of the components, 2 classes of landscapes, 4 subclasses, 12 genera, 94 types of landscapes and 3043 areas are mapped (Starozhilov, 2013).

Our research, which is based on the mapping of landscapes and their structures, evaluating data on the changing properties of landscapes and their spatial-area distribution, is considered not only as basic for a comprehensive assessment of anthropogenic transformations of the natural environment, optimization of environmental management, a constructive start in ensuring environmental safety of environmental management, but and as basic concepts of landscape-ecological nodes still not developed in Pacific Russia, and in general Russia new structures for the development and optimization of the natural environment of the regions in the Landscape Sphere (Starozhilov \& Zonov, 2009; Starozhilov, Kovaleva, \& Derbentseva, 2012).

In addition, as the basic basis for the consideration of landscape-ecological nodal structures of development, we used materials from previously performed studies of the practical implementation of the landscape approach using landscape indication in various areas of environmental management (Starozhilov et al., 2009b; Starozhilov, 2004b, 2013, 2018):

1) an integrated establishment of the landscape status of environmental facilities in the existing landscape system of the region;

2) regional identification and assessment of environmental and environmental 
problems;

3) features of possible anthropogenic transformations of landscapes during nature management;

4) the strategy of practical implementation of the landscape approach in the field of tourism and recreation, urban planning, organization of agricultural enterprises to create a production base in the mountain-taiga landscapes, forest management, planning and design of environmental management (Starozhilov, 2009).

When considering the concept of landscape-ecological nodal structures, materials from the previously considered component, morphological, areal and other landscape indications were used (Starozhilov, 2015a, 2017b), which often serves as the basis for choosing the main direction or even the management strategy (Starozhilov, 2017). The materials of the previously developed concept of the poly-scale landscape indication were also used (Starozhilov, 2017a). The materials include the fact that landscape indication should be carried out on a standard geographical scale of territory mapping and carried out using cartographic vector-layer bases on landscape scale layers: facies, tracts, landscapes, species, genus, subclasses, classes, types, districts, provinces, regions, countries, belts, etc. In general, it is poly-scale and should be carried out using modern digital computer technologies with the mandatory compilation of databases on layers of vector-layer scale levels and taxa, as well as on the types and stages of object display we have considered earlier.

The materials of research of the Institute of Geography of the Far Eastern Branch of the Russian Academy of Sciences on the economic geography of Far East production (Geosystems of the Russian Far East at the Turn of the XX-XXI Centuries, 2010; Long-Term Program of Nature Conservation and Rational Use of Natural Resources of the Primorsky Territory until 2005, 1990; Zaikanov, 2008; Romanov, 2009).

\section{Results and Discussion}

As a result of the synthesis, analysis and evaluation of landscape materials in the Pacific landscape belt of Russia (an example of a landscape sphere link), complex differentiation of landscape systems was established at the level of tracts, localities, species, genera, subclasses, classes, types, districts, provinces, regions, belts. Each of the landscapes of the territory under consideration is characterized by its internal physiographic content and they can be favorable or unfavorable for development, basic (natural foundation) depending on the internal content when planning and forecasting industry production. Allocation of favorable basic landscape structures for the development of natural systems was carried out using the example of synthesis, analysis and assessment of the morphological structures of landscapes and materials for the location of production of the Primorsky Territory (Vostretsov et al., 2008), as well as those noted above results of practical implementation of the landscape approach in various areas of devel- 
opment of the territories under consideration. Analysis and comparison of the integrated placement of industrial production centers for landscape sections and materials on landscape zoning (using the example of Primorsky Krai) shows that in natural terms, most of the main production centers are located in the most favorable natural landscape structures that are proposed to be called nodal. In particular, in Primorye, from the selected 12 landscape provinces and 54 landscape districts, the West Primorsk and South Primorsk provinces and the Muraviev-Amur district are the most developed (including the Russian Island). The noted structures today (as evidenced by the real decisions of the Russian leadership) are favorable for sectoral development; at present, they are intensively developed and we refer to the landscape nodal structures for development.

It can also be said that landscape nodal structures are basic not only for general synthesis, analysis and assessment of the possibilities of economic, social and other types of development, but also sectoral. In particular, the nodal structures of development act as a basis (natural foundation) for designing and forecasting the development and dynamics of a wide variety of production systems, such as forest management, biodiversity, land management, construction, tourism, and many others. However, it should be noted that the most complete optimization and harmonization of nodal landscape structures and economic, social, ecological and other systems is possible when mapping territories, applying methods for indicating inert and bioscreen systems at the polyscale level and in the previously proposed classification units of landscapes (landscape, species, genus, subclass, class, type, district, province, region, belt).

In general, discussing the general principles of the concept of landscape-ecological nodal structures as a natural basis for managing areas of land development harmonized with nature, it is necessary to have primarily a digitized vector-layer morphological basis, which at the digital level gives knowledge of the structure of the geographical space involved in the development of landscape structures. Such materials, as shown by studies on the example of mining and industrial systems (mining industry) and studies on the practical implementation of the landscape approach in various industries, allow us to analyze the areas being mastered in digitized landscape sections. Then compare the internal content of the sections, choose the most favorable (nodal) of them for involvement in the development and then, taking into account the natural landscape data, proceed to planning, forecasting and drawing up development projects. As a result, for any type of development, natural conditions will be taken into account and the task of industrial development of territories harmonized with nature will be performed using digital mapping.

\section{Conclusion}

Identification of landscape-ecological nodal structures of development, as the most favorable landscape morphological structures with natural characteristics that meet the requirements of society for economic, social, environmental and 
other forms of activity necessary to meet the needs of society, is a promising direction of landscape geography. Subject to the use of vector-layer mapping, the study of landscapes using component, morphological, areal, poly-scale vector-layer display in the classification units of landscapes (landscape, type, genus, subclass, class, type, district, province, region, belt), will allow cartographically using modern digital computer technologies at the level of the Landscape Sphere to move on to the consideration of scientific and practical tools for planning and forecasting that are harmonized with nature FIR, social, ecological and other geosystems. Selection of landscape nodal structures for the development of the $s$ Pacific landscape belt of Russia and the landscape sphere as a whole will contribute to solving the problems of optimizing the natural environment of the regions. At present, the FEFU Pacific International Landscape Center is developing a conceptual methodology for digital mapping of hub landscape-ecological structures and the possibility of using these materials in developing the territory of Pacific Russia. We hope that, over time, the application of the proposed concept of landscape-ecological nodal development structures will take a worthy place in the Government's policy in the development of Pacific Russia and other regions of the Landscape Sphere.

\section{Conflicts of Interest}

The author declares no conflicts of interest regarding the publication of this paper.

\section{References}

Geosystems of the Russian Far East at the Turn of the XX-XXI Centuries: In 3 Volumes (2010). Natural Resources and Regional Environmental Management. P. I. Baklanova, \& V. P. Karakina (Eds.). Vladivostok: Dal'nauka. T. 2. 560.

Long-Term Program of Nature Conservation and Rational Use of Natural Resources of the Primorsky Territory until 2005 (Environmental Program) (1990). Vladivostok: Far East Branch of the USSR Academy of Sciences, Part 1, 349; Part 1 (continued), 350; Part 2, 301.

Romanov, M. T. (2009). Territorial Organization of the Economy of Poorly Developed Regions of Russia (p. 318). Vladivostok: Dal'nauka.

Starozhilov, V. T. (1990). Structural-Tectonic Zoning of the Pionersko-Shelta Zone of the East Sakhalin Mountains. Pacific Geology, № 3, 90-96.

Starozhilov, V. T. (2004a). Geodynamic Evolution of the Transition Zone of Northeast Asia to the Pacific Plate. In Collection: Hydrometeorological and Geographical Research in the Far East (pp. 85-87). Vladivostok: Publishing House Dalnevost.

Starozhilov, V. T. (2004b). Landscape Mapping and Geodynamic Evolution of the Foundation of the Far Eastern Territories. In Noospheric Changes in the Soil Cover: Materials of the International Scientific-Practical Conference (pp. 174-178). Vladivostok: Publishing House Dalnevost.

Starozhilov, V. T. (2009). Geoecology of the Mineral Resource Use of Landscapes in the South of the Far East (pp. 47-53). Vladivostok: Ministry of Education and Science of the Russian Federation, Federal Agency for Education, Far Eastern Branch of the Rus- 
sian Academy of Sciences, Institute of Mining, Far Eastern Federal University.

Starozhilov, V. T. (2010). Landscape Zoning of Primorsky Krai, Vestn. FED RAS, No. 3, 107-112.

Starozhilov, V. T. (2011). General Landscape Science and the Use of Landscape Approach in Environmental Monitoring of Environmental Management (p. 297). Vladivostok: Ministry of Education and Science of the Russian Federation, Federal Agency for Education, Far Eastern Federal University.

Starozhilov, V. T. (2013). Landscape Geography of Primorye (Regional Component Specificity and Spatial Analysis of Geosystems) (Part 1, p. 276). Vladivostok: Publishing House of the Far East. Feder. University.

Starozhilov, V. T. (2013). The Marginal Continental Landscape Belt as a Geographical Unit of Pacific Russia. In Sustainable Environmental Management in Coastal-Marine Zones: Materials of the International Conference (pp. 38-42). Vladivostok: Dal'nauka.

Starozhilov, V. T. (2015a). Landscape Indication of the Transformation of Geosystems Structural Transformations in the Geosystems of Northeast Asia: Materials of All. In Scientific-Practical Conference (pp. 86-91). Vladivostok: Dal'nauka.

Starozhilov, V. T. (2015b). Statistical Analysis of the Spatial Distribution of Landscapes of Marginal-Continental Geosystems of Pacific Russia. In Proceedings of the All-Russian School-Conference: "Archach Readings-2015: Earth Sciences and the Strategy of Sustainable Development”(pp. 102-112). Vladivostok: Dal'nauka.

Starozhilov, V. T. (2016). Landscape Geosystems of the Sakhalin Link of the Marginal Continental Landscape Belt of Pacific Russia. Problems of Regional Ecology, № 5, 53-57.

Starozhilov, V. T. (2017a). The Concept of a Poly-Scale Vector-Layered Indication of Landscape-Area Geosystems, in Collection: Fundamental and Applied Research in the Science of the 21st Century. Step into the Future (pp. 44-48). Collection of Scientific Articles on the Results of the International Scientific-Practical Conference.

Starozhilov, V. T. (2017b). The Concept of Areal Landscape Indication in the Policy of the Pacific International Landscape Center SHEN FEFU, Modern View of the Future of Science: Priority Directions and Development Tools: Coll. Scientific St. on the Basis of the Intern. In Scientific-Practical Conference (pp. 37-39). KultInform Press Publishing House.

Starozhilov, V. T. (2018). Landscape Geography of the South of the Pacific Landscape Belt of Russia, (Regional-Component Specificity and Spatial Analysis of Geosystems Using the Example of the Primorsky Territory) (p. 316). Vladivostok: Publishing House Dal'nevost.

Starozhilov, V. T., \& Zonov, Yu. B. (2009). Research Landscapes of Primorsky Krai for Environmental Purposes. Geography and Natural Resources, No. 2, 94-100.

Starozhilov, V. T., Derbentseva, A. M., Stepanova, A. I., \& Oznobikhin (2008). Landscape Conditions for the Development of Erosion-Denudation Processes in the South of the Far East (un-one, 100). Vladivostok: Publishing House Dal'nevost.

Starozhilov, V. T., Evseev, A. B., Tkachenko, V. I., Derbentseva, A. M., \& Stepanova, A. I. (2009a). The Processes of Mechanical Soil Degradation in Landscapes in Primorye (p. 101). Vladivostok: Publishing House Dal'nevost.

Starozhilov, V. T., Kovaleva, G. V., \& Derbentseva, A. M. (2012). Soils and Man-Made Surface Formations in Urban Landscapes (pp. 78-85). Vladivostok: Ministry of Education and Science of the Russian Federation, Far Eastern Federal University, Biology and Soil University, Pacific State University. 
Starozhilov, V. T., Krupskaya, L. T., Grehnev, N. I., Zvereva, V. P., Novorotskaya, A. G., Derbentseva, A. M. (2009b). Ensuring the Environmental Safety of Sources of Environmental Risk in the Tin-Mining Enterprises of the South of the Far. Bulletin of Peoples' Friendship University of Russia. Series: Ecology and Life Safety, No. 4, 81-88.

Vostretsov, Yu. E., Kononenko, N. A., Sergeev, O. I., Turaev, V. A., Gallyamova, L. I., Mandrik, A. T., Proskurina, K. I., Vashchuk, A. S., Medvedeva, L. M., Ivanov, V. V., Tashchi, S. M., Krylov, I. I., Larentseva, S. I., Zonova, I. G., Yakovleva, L. M., Za Na, U. N., Oznobikhin, V. I., Rosenberg, V. A., Krasnopeev, S. M., Kudryavtseva, E. P. et al. (2008). Atlas of Primorsky Krai. Vladivostok: Publishing House Dal'nevost.

Zaikanov, V. G. (2008). Methodical Foundations of a Comprehensive Geo-Environmental Assessment of the Territory (p. 81). Moscow: Science. 